\section{Rapidly progressive antineutrophil cytoplasm antibodies associated with pulmonary-renal syndrome in a 10-year-old girl}

Pediatric Intensive Care U nit, H ospital Infantil M enino Jesus, São Paulo, Brazil
- Fermin Blanco Filho

- Luci Carla Ernesto

- Mônica Assis Rosa

- Luis Antônio Stuginski

- Eliana Regina Zlochevsky

- Fernando Blanco

\section{INTROODUCTIOON}

The term pulmonary-renal syndrome has frequently been used to describe the clinical manifestations of a great number of diseases in which pulmonary hemorrhage and glomeruIonephritis coexist. It consists of a group of complex and often severe disorders that, although rare in incidence, may occasionally be encountered in an Intensive $\mathrm{C}$ are $\mathrm{U}$ nit.

The classic example of this type of vasculitis is Goodpasture's syndrome, a term used to describe the association of pulmonary hemorrhage, glomerulonephritis and circulating antibodies against glomerular basement membrane (anti-G BM ). ${ }^{1}$

In 1958, Stanton and Tange ${ }^{2}$ suggested the term Goodpasture's syndrome to describe a series of young male patients with pulmonary hemorrhage and glomerulonephritis, quite similar to the patient described by Goodpasture in $1919 .{ }^{3}$ It was not until the 1980's, when assays for antineutrophil cytoplasm antibodies (AN CA) were developed, that an association with systemic vasculitides was established. ${ }^{4,5}$ Among the several types of systemic vasculitides that can present clinical manifestations of the pulmonary-renal syndrome, aside from $\mathrm{G}$ oodpasture's syndrome, are included: systemic lupus erythematosus, $\mathrm{H}$ enoch-Schonlein purpura, mixed cryoglobulinemia and more frequently, Wegener's granulomatosis and microscopic polyangiitis. ${ }^{6}$ We focus the discussion on two types of vasculitides more often associated with antineutrophil cytoplasm antibodies (AN CA), microscopic polyangiitis and Wegener's granulomatosis, concerning a 10 year old girl with signs and symptoms of pulmonary-renal syndrome, with positive AN CA antimyel operoxidase (anti-M PO) and rapidly progressive evolution.

Even though AN CA and anti-GBM assays are not routinely available in our laboratories, it is crucial to have an early diagnosis of the disorders responsible for pulmonary-renal syndrome because of the danger of rapid, irreversible renal failure or fatality from massive lung hemorrhage.

\section{CASE REPORT}

A 10-year-old white girl believed to have been in good health previously, was admitted to the Pediatric Intensive C are U nit after an episode of massive hemoptysis and respiratory distress. She was referred to our hospital for evaluation of profound anemia detected in a primary health center.

Five days before entry she had experienced malaise, pallor and began to cough up bloodtinged sputum, at first attributed to dental bleeding. She was admitted to the infirmary with hemoglobin $=4 \mathrm{mg} / \mathrm{dL}$, hematocrit = $14 \%$, platelets $=260,000 / \mathrm{mm}^{3}$, white blood cells $=8300 / \mathrm{mm}^{3}, 74 \%$ segmented, $4 \%$ eosinophils, 19\% lymphocytes and 3\% monocytes. Radiographs of the chest revealed bilateral diffuse interstitial alveolar infiltrates. After laboratory examinations were done, she received packed red blood cells and intravenous cefalotin was started. There was progressive worsening of the cough and respiratory distress during the admission day, when she began to cough up large quantities of blood and was transferred to the Pediatric Intensive $C$ are U nit.
ABSTRACT

CONTEXT: The term pulmonary-renal syndrome has been used frequently to describe the clinical manifestations of a great number of diseases in which pulmonary hemorrhage and glomerulonephritis coexist. The classic example of this type of vasculitis is Goodpasture's syndrome, a term used to describe the association of pulmonary hemorrhage, glomerulonephritis and the presence of circulating antiglomerular basement membrane antibodies (antiG BM). Among the several types of systemic vasculitides that can present clinical manifestations of the pulmonary-renal syndrome, we focus the discussion on two types more frequently associated with antineutrophil cytoplasm antibodies (AN CA), microscopic polyangiitis and W egener's granulomatosis, concerning a 10 year old girl with clinical signs and symptoms of pulmonary-renal syndrome, with positive ANCA and rapidly progressive evolution.

CASE REPORT: $W$ e describe the case of a 10 -year-old girl referred to our hospital for evaluation of profound anemia detected in a primary health center. Five days before entry she had experienced malaise pallor and began to cough up blood tinged sputum that was at first attributed to dental bleeding. She was admitted to the infirmary with hemoglobin $=4 \mathrm{mg} / \mathrm{dL}$, hematocrit $=14 \%$, platelets $=260,000$, white blood cells $=8300,74 \%$ segmented, $4 \%$ eosinophils, $19 \%$ lymphocytes and $3 \%$ monocytes. Radiographs of the chest revealed bifferealed bilateral diffuse interstital alveolar infiltrates. There was progressive worsening of cough and respiratory distress during the admission day, when she began to cough up large quantities of blood and hematuria was noted. There was rapid and progressive loss of renal function and massive lung hemorrhage. The antineutrophil cytoplasm antibody (AN CA) test with antigen splasmantibody (ANCA) test with antigen specificity for myeloperoxidase (anti-M PO) was positive and the circulating anti-G BM showed an indeterminate result.

KEY WORDS: Pulmonary-renal syndrome. AN CA. Vasculitis. 
$\mathrm{H}$ er past medical history and the family history were noncontributory.

The physical examination upon admission revealed a pale $4+/ 4+$ girl weighing 33 kilogram and $138 \mathrm{~cm}$ tall, (NCHS weight by length between 50 th and $75^{\text {th }}$ percentiles), Tanner stage 1, tachypneic $2+/ 4+$, dyspneic $2+1$ $4+$ with intercostal and subdiaphragmatic retractions, temperature $37 \stackrel{\circ}{ } \mathrm{C}$, pulse 118/ minute, respiratory rate $60 /$ minute, blood pressure $120 / 60 \mathrm{mmH}$ g, pulse oxymetry $98 \%$, normal heart sounds, no murmurs. D iffuse, coarserhonchi and crackles were heard in both lung fields. Theliver was palpable $2 \mathrm{~cm}$ below the right costal margin. There was no edema, cyanosis or signs of deep vein thrombosis, nor cutaneous lesions that could suggest the presence of vasculitis.

Laboratory studies showed a prothrombin time of 14.8 seconds, partial thromboplastin time of 33.6 seconds; hemoglobin $8.0 \mathrm{~g} / \mathrm{dL}$; hematocrit $24 \%$ after blood transfusion while at the infirmary; serum sodium $136 \mathrm{mEq} / \mathrm{L}$; potassium $5.6 \mathrm{mEq} / \mathrm{L}$; blood urea nitrogen $163.2 \mathrm{mg} / \mathrm{dL}$; serum creatinine $6.13 \mathrm{mg} / \mathrm{dL}$; urinalysis showed specific gravity of $1010, \mathrm{pH}$ 5.0 , protein $2+$, occult blood $2+$, W BC 8500 / $\mathrm{mL}, \mathrm{RBC} 240,000 / \mathrm{mL}$, casts were not observed; negative direct and indirect Coombs tests; normal hemoglobin electrophoresis; negative anti-HIV. Laboratory assays for antineutrophil cytoplasm antibodies (AN CA) revealed indirect immunofluorescence for $p$ ANCA (perinuclear) with titer 1:80, and cAN CA (cytoplasmic) negative. The enzyme linked immunosorbent assay (ELISA) antimyel operoxidase ( $p-A N C A$, anti-M PO) was positive and the ELISA anti-GBM result was $6.0 \mathrm{UE} / \mathrm{mL}$.

Serial radiographs of the chest revealed a diffuse increase in bilateral interstitial alveolar infiltrates. There was rapid and progressive worsening of the breathing pattern with massive pulmonary hemorrhage and mechanical ventilation was started. $M$ assive bleeding came up from the tracheal tube during aspiration procedure and she presented a cardiac arrest. Cardiopulmonary resuscitation was successfully achieved after one epinephrine dose. Arterial blood gases drawn fifteen minutes after resuscitation showed $\mathrm{pH}$ 6.8, $\mathrm{PaCO}_{2} 45 \mathrm{mmH} \mathrm{g}, \mathrm{PaO}_{2} 110 \mathrm{mmH}$, and bicarbonate $8.6 \mathrm{mEq} / \mathrm{L}$. The patient remained in shock despite the administration of fluid volume, vasoactive drugs and packed red cells. The renal function deteriorated rapidly with oligoanuria and gross hematuria. Peritoneal dialysis was started and the clinical course continued to worsen. Her condi- tion deteriorated fast and she died before the institution of glucocorticosteroids and immunosuppressive therapy.

........ DISCUSSION

The systemic vasculitides consist of a broad group of heterogeneous pathologies, whose diagnosis and classification still today remain a great diagnostic challenge. ${ }^{7,8,9}$ Even though there is no universal acceptance, nowadays a tendency exists towards the use of the nomenclature proposed by the International Consensus Conference published in 1994. ${ }^{10}$ According to that classification, the pulmonary-renal syndrome can be divided into three groups:

Little or no immune deposits in the vascular wall (pauci-immune), frequently associated with antineutrophil cytoplasm antibodies (AN CA): W egener's granulomatosis, microscopic polyangiitis and Churg-Strauss syndrome;

Immune complex deposits: H enochSchonlein purpura, cryoglobulinemia and other types of vasculitides of small vessel such as systemic lupus erythematosus and serum sickness;

Anti-glomerular basement membrane antibody (anti-GBM) deposits: Goodpasture's syndrome.

$W$ ith the development of assays for antineutrophil cytoplasm antibodies (AN CA), during the 1980's, and the later association with vasculitis (firstly with Wegener's granulomatosis), ${ }^{11}$ this complex group of diseases began to have a laboratory test of great diagnostic value when associated to the clinical signs and symptoms presented by the patient. ${ }^{4,5,12,13}$ These classes of specific autoantibodies against neutrophils and monocytes in cytoplasm present two immunofluorescence staining patterns when the patient's serum is incubated with normal human neutrophils fixed in ethanol. The first pattern produces accentuated immunofluorescence in the central area of neutrophil cytoplasm (cAN ( A), and is constituted in its great majority by autoantibodies against the enzyme proteinase 3 of the azurophilic granules (antiPR 3); T he other pattern, called perinuclear ( $p$ ANCA), is frequently associated with autoantibodies against myel operoxidase (antiM PO ), producing perinuclear or nuclear immunofluorescence. ${ }^{6,14,15} \mathrm{~T}$ he positivity of these autoantibodies is fundamental for the differential diagnosis of pulmonary-renal syndrome, firstly because it restricts that group of vasculitides practically to three entities: Wegener's granulomatosis, microscopic polyangiitis and Churg-Strauss syndrome, and also because they are highly sensitive and specific serological markers for those diseases, when serum is tested by indirect immunofluorescence combined with enzyme immunoassays for both PR3 and M PO ., 5,12,16 T he C hurg-Strauss syndrome can be excluded from this discussion because, by definition, it demands the presence of asthma and eosinophilia, ${ }^{10}$ which were not found in the described case.

Although the pathogenic role of antineutrophil cytoplasm antibodies has not yet been proven in these forms of pauci-immune vasculitides, recent evidence suggests that they are directly involved in the mediation of the vascular inflammatory process. ${ }^{4,17,18}$ Thefinding of antineutrophil cytoplasm antibodies in a patient with manifestations of pulmonary-renal syndromeishighly suggestive of the presence of microscopic polyangiitis or Wegener's granulomatosis. ${ }^{6}$ T he AN CA with cytoplasmic pattern (C-ANCA) and antigen specificity for proteinase 3 (anti-PR3) are very sensitive serological markers for Wegener's granulomatosis.

Patients with signs and symptoms of pulmonary-renal syndrome caused by Wegener's granulomatosis present, in their vast majority, positivity for antineutrophil cytoplasm antibodies with C-AN CA pattern anti-PR3. ${ }^{10} \mathrm{~Pa}$ tients with microscopic polyangiitis can present positive ANCA with perinuclear pattern ( $p$ AN CA) anti-M PO or cytoplasmic pattern (CAN CA) anti-PR 3.

The AN CA-associated pulmonary-renal syndrome, p-ANCA positive with antigen specificity for myeloperoxidase (anti-M PO), is almost always caused by microscopic polyangiitis ${ }^{10}$ and this association can bemanifested as severe lung hemorrhage and rapidly progressive renal failure, ${ }^{15}$ as happened with our patient.

It is important to point out that patients with these forms of vasculitides typically present positivity either for C-AN CA anti-PR 3 or for $\mathrm{p}$-AN CA anti-M PO, but virtually never for both types.

In addition, the systemic vasculitides that present the association with pulmonary hemorrhage and glomerulonephritis have AN C A circulating more frequently than antiGBM autoantibodies, ${ }^{6}$ even though, on rare occasions, both can coexist in the same patient. ${ }^{19,20,21} \mathrm{O}$ ur patient presented an indeterminate result for circulating anti-GBM antibodies (6.0 UE/mL). To be considered positive it should demonstrate a value greater than $20.0 \mathrm{UE} / \mathrm{mL}$. 
Bosch et al. ${ }^{22}$ presented a large case series showing that AN CA anti-M PO are highly sensitive and specific markers for glomerular and alveolar necrotizing capillaritis (vasculitis), irrespective of the primary underlying condition. The interpretation of these data allows us to maketherapeutic decisionsin situations where there is risk to life, in which a histological diagnosis (biopsy) cannot be accomplished. Therefore, the detection of anti-M PO autoantibodies in patients with impaired renal function and lung hemorrhage strongly suggests the presence of glomerular and alveolar capillary vasculitis that, as previously mentioned, can run a rapidly progressive and fatal course.

The clinicopathological diagnosis of the two main types of vasculitis associated with AN C A (Wegener's granulomatosis and microscopic polyangiitis) often overlap, making it difficult to differentiate between them. It is not uncommon to find patients with an initial diagnosis of microscopic polyangiitis (a non-granulomatous inflammation) that later on develop granulomatous inflammation typical of Wegener's granulomatosis. ${ }^{14,23}$

Capillaritis is the most common lung vascular lesion observed in patients with either positive p-AN CA or c-AN CA..$^{23,24}$

Although biopsy is considered the most important technique for the clinicopathological diagnosis of diseases associated with AN CA, it is not uncommon to find specimens without consistent evidence of any specific process. The granulomatous lesions characteristic of
W egener's granulomatosis are frequently only observed after several biopsies. ${ }^{14}$ In rapidly progressive ANCA associated pulmonary-renal syndrome, biopsy is obviously not indicated because of the acute deterioration of the patient's general state.

The clinicopathological differentiation of those patients who show positivity for $p$ AN CA anti-M PO is less of a problem, because they only develop granulomatous inflammation on rare occasions. ${ }^{10}$ Therefore it is essential to point out that the important factor lies in the recognition that these autoantibodies are associated with similar pathological processes that can be related to each other and respond basically to the same type of therapy, ${ }^{18}$ namely corticosteroids, immunosuppressors and plasmapheresis. ${ }^{9}$

A nother important fact to be borne in mind is that in this particular case, there were signs of poor prognosis from the time of admission to the Intensive Care U nit, such as acute and rapidly progressive onset, massive hemoptysis and serum creatinine greater than $6 \mathrm{mg} / \mathrm{dL} .{ }^{19}$

Again we would like to emphasize that the AN CA test results, either positive or negative, should always be analyzed together with clinical manifestations presented by the patient if we want the diagnostic significance of these tests to be optimized.

Jennette, W ilkman and Falk ${ }^{13}$ stated clearly that the patient's signs and symptoms are not just essential when we decide to order the ANCA test but especially when in- terpreting the significance of the results. We believe that that was an unusual presentation of some type of vasculitis, probably making microscopic polyangiitis the leading possibility clinically.

As stated before, there were many signs of poor prognosis, especially featuring serum creatinine $>6 \mathrm{mg} / \mathrm{dL}$ at presentation and massive hemoptysis, which substantially increase the mortality rate. ${ }^{16}$

Cases like this, with such an acute presentation, almost invariably run a fatal course even when the immunosuppressive treatment is instituted early. ${ }^{19} \mathrm{~T}$ heclinical course deteriorated so quickly after the admission to the PICU, when the case was presented to us, that we had not enough time to plan and institutethemost suitable immunosuppressive treatment. Plasmapheresis was not indicated because she developed a cardiac arrest and remained in shock soon after admission to the PICU .

O ur aim in presenting this case is to alert clinicians that, even without the definitivehistological diagnosis, it is possible, based on clinical history and physical examination, and whenever possibleserological tests (AN CA and anti-GBM ), to start immunosuppressive therapy, that can avoid the irreversible loss of renal function and interrupt the fatal course of lung hemorrhage.

We could not finish this discussion without mentioning this providential statement from Jennette et al:13 "As with any tool, the usefulness of AN CA testing is dictated by the skill of the individual who uses it."

REFEREN CES

1. Ball JA, Young Jr KR. Pulmonary manifestations of G oodpasture's syndrome- Antiglomerular basement membrane disease and related disorders. Clinics in Chest Medicine 1998;19:777-91

2. Stanton M C, Tange JD. Goodpasture's syndrome (pulmonary haemorrhage associated with glomerulonephritis). Austr Ann M ed 1958;7:132-44.

3. GoodpastureEW. The significance of certain pulmonary lesions in relation to the etiology of influenza. Am J M ed Sci 1919;158:863-70.

4. N ash M C, Dillon M J. Antineutrophil cytoplasm antibodies and vasculitis. Arch D is Child 1997;77(3):261-4.

5. Goeken JA. Antineutrophil cytoplasmic antibody - A useful serological marker for vasculitis. J Clin Immunol 1991;11(4):161-74

6. Niles JL, Bottinger EP, Saurina GR, Kelly KJ, Collins AB, $M$ cCluskey RT. The syndrome of lung hemorrhage and nephri- tis is usually an AN CA-associated condition. Arch Intern M ed 1996;56:440-5

7. Cuttica RJ. Vasculitis in children: A diagnostic challenge. Curr Probl Pediatr 1997;27:309-18.

8. Athreya BH. Vasculitis in children. Pediatr Clin N orth Am 1995;42(5):1239-61.

9. Hunder G. Vasculitis: diagnosis and therapy. Am J M ed 1996;100(suppl 2A):37S-45S

10. Jennette JC, Falk RJ, Andrassy K, et al. Nomenclature of systemic vasculitides - Proposal of an international consensus conference. Arthritis Rheum 1994;37:187-92.

11. Van der Woude FJ, Rasmussen N, Lobatto $S$, et al. Autoantibodies against neutrophils and monocytes: tool for diagnosis and marker of disease activity in Wegener's granulomatosis. Lancet 1985;i:425-9.

12. H agen EC, D aha M R, H ermans J, et al. D iagnostic value of standardized assays for anti-neutrophil cytoplasmic antibodies in idi- opathic systemic vasculitis. Kidney Int 1998:53(3):743-53.

13. Jennette JC, Wilkman AS, Falk RJ. Diagnostic predictive value of AN CA serology: (editorial). Kidney Int 1998;53:796-8.

14. Bosch $X$, Font J. The pulmonary-renal syndrome: a poorly understood clinicopathologic condition. Lupus 1999;8:258-62.

15. Roberts DE, Peebles C, Curd JG, Tan EM, Rubin RL Autoantibodies to native myeloperoxidase in patients with pulmonary hemorrhage and acute renal failure. J Clin Immunol 1991;11(6):389-97.

16. Savige J, D avies D, Falk RJ, Jennette JC, W iik A. Antineutrophil cytoplasmic antibodies and associated diseases: a review of the clinical and laboratory features. Kidney Int 2000;57(3):846-62

17. $\mathrm{H}$ arper $\mathrm{L}$, Savage $\mathrm{CO}$. Pathogenesis of AN CA-associated systemic vasculitis. J Pathol 2000;190(3):349-59.

18. Beer DJ. ANCAS Aweigh (editorial). Am Rev Respir Dis 1992;146:1128-30.

19. Scully RE, M arc EJ, M cN eely WF, M cN eely BU. C ase records 
of the M assachusetts General H ospital. N Engl J M ed 1993;329(27):2019-26.

20. Paueksakon P, H unley TE, Lee SM, Fogo AB. Renal biopsy teaching case: a 12-year-old girl with pulmonary hemorrhage, skin lesions, and hematuria. Am J Kidney D is 1999;33(2):4049 .

21. Bosch X, M irapeix E, Font J, et al. Prognostic implication of anti-neutrophil cytoplasmic autoantibodies with myeloperoxidase specificity in anti-glomerular basement membrane disease. Clin Nephrol 1991;36:107-13.

22. Bosch X, M irapeix E, Font J, et al. Anti-myeloperoxidase autoantibodies in patients with necrotizing glomerular and alveolar capillaritis. Am J Kidney D is 1992;20(3):231-9.

23. Gaudin PB, Askin FB, Falk RJ, JennetteJC. The pathologic spec- trum of pulmonary lesions in patients with anti-neutrophil cytoplasmic autoantibodies specific for anti-proteinase 3 and antimyeloperoxidase. Am J Clin Pathol 1995;104(1):07-16.

24. Bosch X, Soto AL, M irapeix E, Font J, Ingelmo M, M árquez AU . Antineutrophil cytoplasmic autoantibody - Associated alveolar capillaritis in patients presenting with pulmonary hemorrhage Arch Pathol Lab M ed 1994;118:517-22.
..Publish ing in for mat io n .

Acknowledgment: We are grateful to Dr. Paulo G. Leser from the Immunology Division, Fleury Laboratory - São Paulo, for kindly performing the ANCA tests and for his help in providing the anti-GBM assays.

Fermin Blanco Filho, MD. Preceptor, Intensive Care Unit, Hospital Infantil Menino Jesus, São Paulo, Brazil.

Luci Carla Ernesto, MD. Resident PL3, Intensive Care Unit, Hospital Infantil Menino Jesus, São Paulo, Brazil.

Mônica Assis Rosa, MD. Resident PL3, Intensive Care Unit, Hospital Infantil Menino Jesus, São Paulo, Brazil.

Luis Antônio Stuginski, MD. Chief, Intensive Care Unit, Hospital Infantil M enino Jesus, São Paulo, Brazil.

Eliana Regina Zlochevsky, MD. Residency Program Director, Hospital Infantil M enino Jesus, São Paulo, Brazil.

Fernando Blanco, MD. Co-ordinator, Pediatric Intensive Care Unit, Santa Casa de Araras, São Paulo, Brazil.

Sources of funding: $\mathrm{N}$ ot declared

Conflict of interest: $\mathrm{N}$ ot declared

Last received: $18 \mathrm{M}$ ay 2000

Accepted: 07 June 2000

Address for correspondence:

Fermin Blanco Filho

UTI, Hospital Infantil M enino Jesus

Rua dos Ingleses, 258 - Bela Vista

São Paulo/ SP - Brasil - CEP 01329-000

E-mail: blancoff@siteplanet.com.br

CO PYRIG HT@2001, Associação Paulista de Medicina

$\ldots \ldots \ldots \ldots \ldots \ldots$ RESUMO

CONTEXTO: 0 termo síndrome pulmonar-renal tem sido usado com freqüência para descrever as manifestações clínicas deum grandenúmero de doenças, nas quais coexistam hemorragia pulmonar e glomerulonefrite. 0 exemplo clássico desse tipo de vasculiteé a síndrome de Goodpasture, um epônimo usado para descrever a associação dehemorragia pulmonar, glomerulonefrite e a presença de anticorpos circulantes anti-membrana basal glomerular (anti-GBM). D entre os vários tipos de vasculites sistêmicas que podem apresentar as manifestações clínicas da síndrome pulmonarrenal, focalizamos a discussão nos dois tipos maisfreqüentemente associados aos anticorpos anti-citoplasma de neutrófilos (AN CA), poliangiite microscópica e granulomatose de Wegener, a propósito de uma menina de 10 anos com sinaise sintomas clínicos da síndrome pulmonar-renal, com ANCA positivo e evolução rapidamente progressiva.

RELATO DE CASO : Nós relatamos o caso de uma menina de 10 anos de idade encaminhada ao nosso hospital para avaliação deanemia profunda detectada em um centro primário de saúde. Cinco dias antes da internação iniciou quadro detosse, hipoatividade, palidez cutânea ealguns escarros com raias de sangue que foram atribuídosa sangramento dentário. Internadana enfermaria com hemoglobina $=4 \mathrm{mg} / \mathrm{dl}$, hematócrito $=14 \%$, plaquetas $=260.000$, leucócitos $=8.300,74 \%$ segmentados, $4 \%$ eosinófilos, $19 \%$ linfócitose $3 \%$ monócitos; Rx tórax com infiltrado interstício alveolar bilateral. Houve piora progressiva da tosse e do desconforto respiratório no mesmo dia da internação, quando apresentou hemoptise maciça e hematúria com evolução rapidamente progressiva para falência renal e hemorragia pulmonar de difícil controle. A sorologia para anticorpos anti-citoplasma de neutrófilos (ANCA), com especificidadeanti mieloperoxidase (anti-M PO), foi positiva e 0 anti-GBM apresentou valor considerado indeterminado.

PALAVRAS-CH AVE: Síndrome pulmonar-renal. ANCA. Vasculite. 